\title{
The New Orleans Carnival as a Theater Space: A Patrimonial Landscape in the Understanding of Translatinity
}

\author{
Christian Dennys Monteiro de Oliveira \\ Geography Department, Federal University of Ceará (UFC), Ceará, Brazil \\ Email: cdennys@gmail.com
}

How to cite this paper: de Oliveira C.D.M. (2019) The New Orleans Carnival as a Theater Space: A Patrimonial Landscape in the Understanding of Translatinity. Open Journal of Social Sciences, 7, 27-41. https://doi.org/10.4236/jss.2019.72003

Received: January 7, 2019

Accepted: January 29, 2019

Published: February 2, 2019

Copyright $\odot 2019$ by author(s) and Scientific Research Publishing Inc. This work is licensed under the Creative Commons Attribution International License (CC BY 4.0).

http://creativecommons.org/licenses/by/4.0/

\section{c) (i) Open Access}

\begin{abstract}
The present study represents an attempt to read the patrimonial landscape composed by the sacred-profane festivities of the New Orleans Carnival, known as Mardi Gras. It uses a methodology of comparative observation and qualitative analytical procedures to link the theatricality of the city to the performance of Afro-descended groups (the "Indians"), the aesthetics of their self-presentation and their engagement in cultural resistance. To do so, the study projects inequalities and cultural shocks with reference to the play $A$ Streetcar Named Desire, by Tennessee Williams. The main purpose is to elaborate a concept of a theater space where it is possible to develop modes of interpretation of the Latin American culture, that is, a "translatinity" a political and social overflow of African and Amerindian values, especially from the second half of the 20th century, in the culturally polarized cities of the American continent.
\end{abstract}

\section{Keywords}

Carnival, Theater Space, Latinity, Patrimonial Landscape

\section{Introduction}

This paper emerges from two touristic experiences in the City of Mardi Gras (New Orleans) and its French-Caribbean cultural context, among other ethnic nuances combined. Different from the urban dinamic that has led to the remaking of the "Momo Festival" in Rio de Janeiro and São Paulo [1], we approach a question of borders between two worlds here, a conservation of the latent design determined by the comings and goings of French colonization-with all its challenges of resistance and abandonment-at the mouth of the Mississippi River, 
like a portal of integration between Africa/Haiti and France/Quebec.

The paper will attempt to advance a performative perspective, rooted in a game of fantastic allegories and surreal dramas. To do so, it was chosen the provocative text of Tennessee Williams (1911-1983), an American playwright who made the city his "spiritual home", A Streetcar Named Desire (1947) [2], his best known theatrical (and later cinematographic) work, closely corresponding to the game of cultural and intrafamily tensions led by the key protagonist, who arrives by streetcar and sets up a "carnival" of intrigues. Williams chooses New Orleans as a privileged stage - a place of encounters and disagreements of conflicting worlds and expectations-not just for the scenes of his creation, but mainly for his personal, familiar, psychological and existential dramas. We are not talking about an author who focused on the creative dynamics of Carnival rituals, but of the one who built the representation of a raw material that is highly processable by the Momo festival.

The revelry metaphor here does not mark an advance into sociocultural modernity; it is the permanent confrontation of people, groups, and perspectives, capable of forging in a stage a carnival float depicting their main challenge: exposing the incurable wounds of disconnected worlds, except for the breaking (as permanent as possible) of the celebration of the party, a thousand and one ways of doing "jazz" and combining it with other sounds generated in the American continent.

What can be called as mobile allegory of Mardi Gras was experienced in January 2017 and March 2018 with two glamorous moments. First is an opening in the Shakespearean production of the Trial of Joan of Arc, in the heart of the French Quarter. It was the official opening of Mardi Gras on the Feast of Kings, January 6. Next is a revision of it in the following year, 2018, in the spectacular Super Sunday, which coincides with St. Joseph's Day, in the parade of one of the oldest African-American groups of Mardi Gras revelers in the city: the so-called Mardi Gras Indians.

Therefore, in New Orleans, we have not only Shrove Tuesday as a day for the "goodbye at meat" that is Carnival, but also have sprees in a season spreading for 3 or 4 months of the year to exercise the right of revelry to its fullest [3]. New Orleans, with its glamor and its crises (environmental and social), replays what we already know well about the problematic context of other Latin Carnival centers, like Rio de Janeiro, Barranquilla, or Veracruz: Carnival was and still is artifice of the Roman Catholic heritage to contain, in a single day, the festive theater of the whole year. The result of this clash is the return of the feast to its pre-Catholic condition. That is, a carnival cycle from the Christmas period (December) to Easter (March/April). The "goodbye to meat" that baptizes it is being increasingly reconfigured in the Carnival floats (carrus navalis), masks and poetics that reinvent it [4].

Having understood the initial provocation-which in principle claims the Carnival to be a season, a stop, a complete cycle, we must dedicate ourselves to the means by which it becomes relevant, especially in the composition of 
Afro-Amerindian "spheres" (networks) with Latinities in transit (translatinity), a renewed matrix of the cultural landscape of the continent.

Composite spheres are metaphors of the thematic-referential field around which the geographic amplitude of the Carnival is intended to rotate (move with a recurring rhythm), as a pattern of celebration, constituting at the same time a cultural heritage (the first sphere) and a poetic existentialism (the second sphere). These are the spheres that turn in search of complementarity in symbolic acceleration towards a third sphere: the mythical time of post-modernity, something as medieval as futuristic [5]. We can schematically draw the three spheres in order to delineate the systematic construction of this text itself. After all, the authors and studies with which we intend to debate the Carnival theater of New Orleans are expected to produce a sequence of perceptions, descriptive observations, and collaborative interpretations.

In the first, general perceptions, it is essential to face the no-Manichean struggle of multiple stages, ethnoracially segregated before the creation of reigns in their likeness. The Mardi Gras of "Krewes" (Carnival associations like kingdoms or nations), like Zulu, Indian, Bacchus, Endymion, and Rex (the model for the others, see website http://www.mardigrasneworleans.com/history.html), constitute their own parades in a competition that is not limited to the regulated game to win the Carnival, but also to sustain the "royal" representativeness, the ritualistic empowerment of their nation. Therefore, the perceptions of the cultural heritage of this theater tend to consider a sum of events that, guided by the Shrove Tuesday event, spread different opportunities, although most are able to connect with other power games in the Afro/Latin American world [6].

In the next phase, the selective observations, a point of view of interactive conditioning is established with the practice of getting the seeds of the place and taking them to other similar places. How should we talk about a cultural-historical process without a geography focused on the perspective of these words, that stimulate comparisons? It is in this sense that the poetry of the dramaturgist as the propagator of a method of existentialism for the Carnival experience in its fragments, is evident through the dramatic exercises of Tennessee Williams. This direct correlation of author/city/celebration incorporates a connection to situate the existentialism of the producing leaders of the Mardi Gras Indians, especially Allison "Tootie" Montana (1922-2005) and Big Chief Victor Harris (1956). To what extent will it be possible to read the Super Sunday a "existential streetcar" of Afro-Amerindian reinventions of the Carnival? The geographic dimension of this performative stage is fruitful through the possibility of identification with many events in Latin America [7], whether in or out of Carnival season.

In the third phase, mythical time becomes an interpretative condition for the creation of a collaboration in Carnival landscape design, perhaps as a issue of a semiotic game, that proposes the suspension of the ordinary roles that limit us to the everyday of chance. Carnival is a space of maturity and protagonism, a theater of different peoples and cultures [8]. That landscape that we do not choose or 
design does not ground our legitimate will; it simply does not deserve us. An extraordinary demander of more and more extraordinary situations needs to be created, a constant staging of the festive world. A chrono-landscape, in the Bakhtinian space-time-language design; or the geosophy of the unknown earth has been hailed as the realm of the imagination by John Wright [9]. One has to turn to the myths of the temporal trinity to compose a performance in which the mystics-of the ancestral reverence, the satire of power, and of children's fantasies-can be found in artistic games of attraction and rejection, especially as a modulation of a radially inclusive religiosity: a Carnival religiosity of translating geography.

\section{Mardi Gras Perceptions: A Streetcar Departed from the Station...}

In the meandering mouth of the great Mississippi River, 300 years ago, a French-Hispanic-Indian city took its African American design without losing sight of the many colonial projects that made it. New Orleans is one of the southern gateways to the multicultural polity of the USA and, at the same time, the effective entry of this nation into the club of American countries that have patrimonial landscapes including Carnival, that is, into Latinity.

One of the strongest perceptions one has in this port city of Louisiana (note that contrary to common perception, the capital is the city of Baton Rouge, 81 miles away) is that ancestral memory is a recurring practice in the various celebrations on the calendar of local events. From this starting point, we inquire about the amplitude of the Carnival festivity, or Mardi Gras ("Fat Tuesday" - or Shrove Tuesday, the "farewell to the flesh"-which is the Latin origin of the word Carnival-before the self-denial of Lent). And how far do we need to correct this punctual condition to read between Christmas and Easter, significant marks of an expanding Carnival cycle?

The French origins of Mardi Gras in this Orleans in the New World reflect that the need to display the splendor of social and economic elites, especially in the changes of the nineteenth century, created the need for a more extensive than intensive program for the Carnival. In dealing with dramatic catastrophes-whether colonial conquests or extreme weather phenomena-this "Big Easy" (the suggestive nickname of New Orleans) built a contemporaneity full of scenic effects, beginning with the fact that the urban differential of the French Quarter, heritage served up to tourists, is a major identity signifier for the whole state of Louisiana, which historically encompassed the Midwest of the United States as far as the Canadian territory (Figure 1).

An updated French culture in the Caribbean basin, built in conflict and dialogue with the British, Spanish, Dutch, and Portuguese empires, expresses the clearest representation of the contemporary Latin Carnival design. In this sense, it becomes fundamental to conceive the performative multiplicity of European ties with this immense Central North American frontier, from a perspective on 


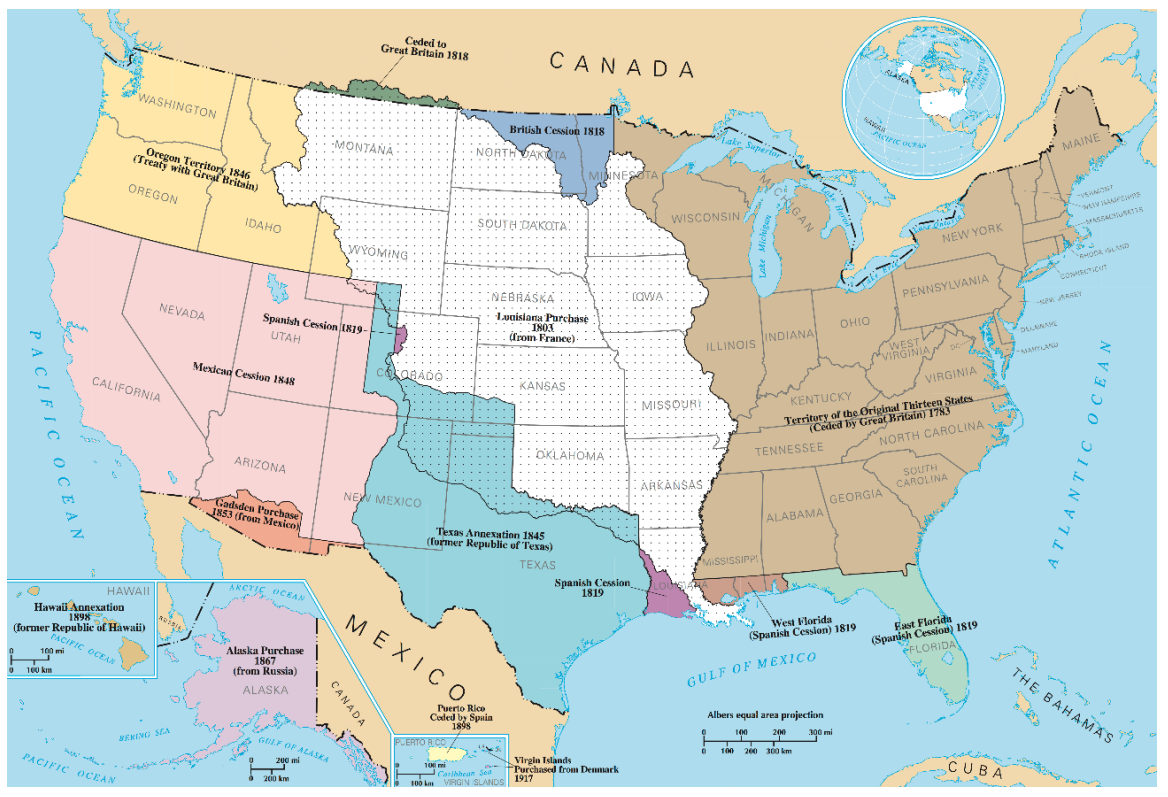

Figure 1. A map of the historical territorial expansion of the United States of America. Source: https://nationalmap.gov/small_scale/printable/territorialacquisition.html (2000).

modernity as a "self-mobility" of the landscapes, a mobile stage capable of putting the viewer directly in the context of the scene, as well as getting him or her to change scenes without losing the whole of that theatricality. A theatrical "streetcar" and its kind with the allegorical trios were chosen to serve as a translation or synthesis of this epic. From this, we establish the mapping of the ritual that founds the French-Caribbean Carnival of New Orleans.

Tennessee Williams captured a mix of domestic and social conflicts in the creation of his key work, A Streetcar Named Desire (1947), and this capture leaves us with the possibility of a "solution" to the problem of shocks to values and incommensurate mentalities. Human needs must be enacted, however contradictory they may be (or become), without letting them break the cultural boundaries of the relationships. New Orleans draws multiple imaginary lines from these boundaries, and so the arrival of the main character in Williams's play, Blanche Dubois, in the house of the couple Stanley and Stella marks a confrontation of an unequal order (macho, classist, exploratory) by hypocritical means, permeated by lies and frustrations. Mariana Alves [10] engages in a Freudian discussion of the play's plot, and registers the density of this shock:

Blanche's "I want magic" breaks with Stanley's "truth", with his life based on work interspersed with moments of relaxation. It is a refusal of reality, an ode to the fiction lived daily as a survival strategy. Blanche is a teacher of English literature. Her refinement and her party dresses do not match the suburban New Orleans. Her Japanese paper lamp, which serves to soften the direct light and make her appear younger, is significant of this inadequacy.... "A Streetcar" constitutes a problematization of the politics of desire. ([4], pp. 4-5) 
However, what should interest us in what Williams captures is found in the extremes: the arrival and departure of Blanche in New Orleans. To bring this "streetcar" as an opening to compose the main line of the plot and bring it in the end to an ambulance to ward off the madness of the main character is to reissue the intermittence of the Carnival theater. Sexuality, family, power, economic crisis, and the exigencies of survival draw a progressively increasing tension. There is, therefore, nothing in the play that directly indicates a Carnival joy.

However, at the same time, paradoxically, everything is indeed an "allegory" of the fantasies that inspire these fragile relationships: from the visitor to the sister, to the brother-in-law, to his flirtation and fundamentally to Blanche herself, hence the dramatic and irreversible ending, which causes the fantasy to undo itself by sending her to a sanatorium. The phrase "Whoever you are... I have always depended on the kindness of strangers" denotes frustration over all attempts to erase the past and at the same time the paradoxical fragility of the powers of modernity. After all, the same loss can be experienced both by those dispossessed of assets and by the representatives of the aristocracy, through the fading of the most significant social and family ties. If this streetcar of Tennessee Williams stands as a single moment of the Carnival parade, what is the moment found for the anticlimax of the post-Carnival Ashes? New Orleans, in its scenic constitution of recomposing traditions and updating tourist demands of various North American investments [11], has made itself into a complex of festivals, all open and keyed to a high pitch to provide a permanent carnivalization. A picture of the annual festivities of the city shows the strength of this process in the last decades (Figure 2).

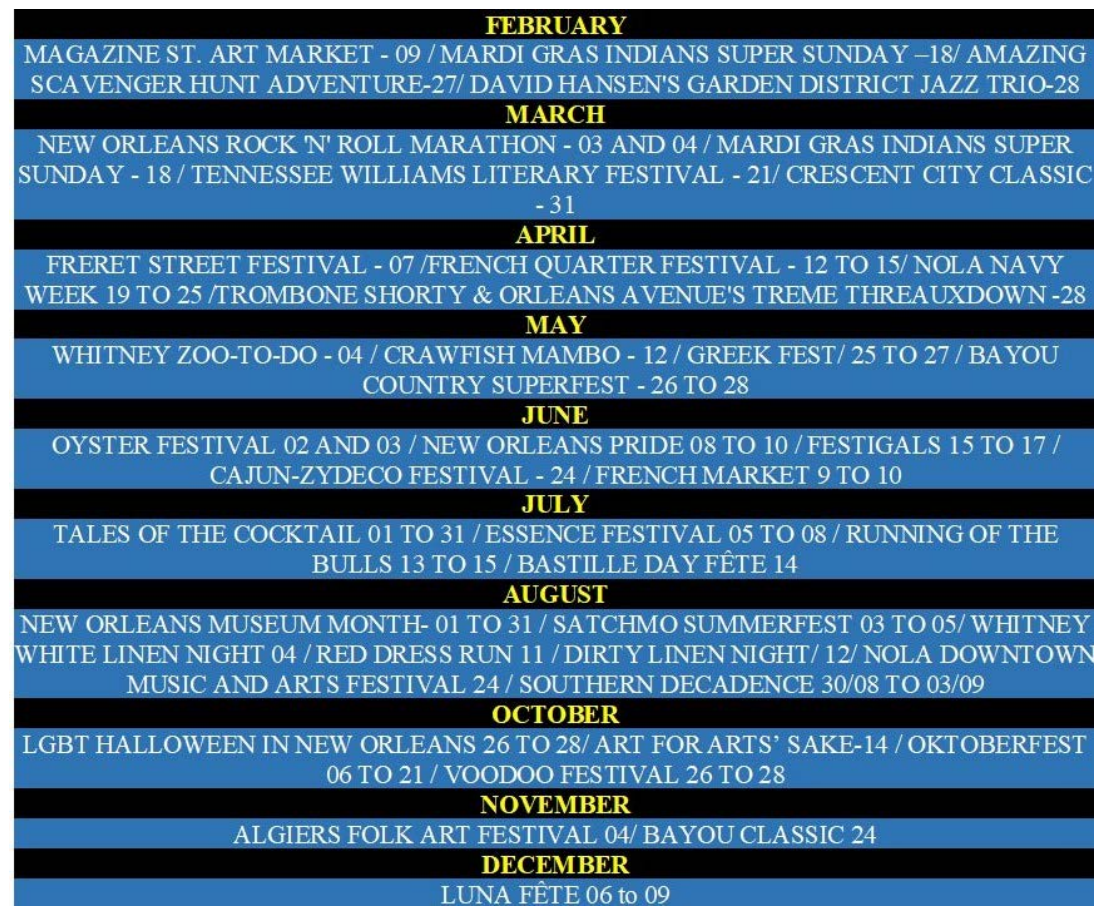

Figure 2. List of events in New Orleans in 2018. Source: http://visitenovaorleans.com.br/ Accessed 20 November 2018. 
Each of these events reproduces an iconic Mardi Gras of the myth of founding that ephemeral reign again, desired in the contradictions of the exotic visit, initiated by a streetcar and ended by an ambulance, of madness and solitude.

\section{African American Observations: The Desires Resist in the Square}

An African American city on the northern shores of the Caribbean Sea, marked by the tumultuous history of tragedy and clashes of colonial empires, would not translate into a "festive paradise" without a huge social price to be paid. A set of segregationist factors over the course of three centuries of formation/deformation of this great port city drew all the marginality of African-descended communities and the permanent massacre to their basic human rights. However, it is this same marginality that creates an insurgent culture of jazz and blues bands, carving what we should observe with more apprehension as "festivities" of the Mardi Gras Indians in their ritual stages.

The core of the African Carnival, especially the "Indians," is found in the ritual tribute to otherness. To what extent does the great (though troubled) Black city of New Orleans absorb the allegory of its major festivities in reverence to the ancestral Indigenous societies? According to Góes [12], the answer to this question is the ability to translate reverence for the festival leaders-such as the Krewes, or the drivers of cars like Carnival floats with people distributing gifts to the population-into a ritualistic, performative spirit. Vested with indigenous power in their sacred American lands, Black societies resisted and reinvented their socio-cultural marks in the repressive and discredited periphery of the so-called Big Easy. The response to oppression is the festive effervescence of the recognized residents in this multifaceted Afro-descendant population.

What we call the "public square," as a projection of collective desire, represents the peripheral recreation space of Euro-Latin centrality, accessible only momentarily in the glamor of the French Quarter. Hence, it is important to think of Mardi Gras in the form of a multiplicity of events, whose culmination point may be much better placed at the Feast of Saint Joseph, before Easter, or at the Jazz \& Blues Festival, so venerated in the city's springtime calendar. In these terms, the Carnival becomes a theatrical reference for many performances and manifestations of the city's cultural carnivalization. Góes [6] argues that squares of desire are more significant in the process of constitution of the theater space than the limited centralizing stage of the streets that form the French Quarter.

New Orleans people are festive and love to decorate and display their beautiful homes, especially in the area originally occupied by the Americans who owned plantations, the Garden District, on the outskirts of Saint Charles Avenue, which has the rails of the famous streetcar that inspired Tennessee Williams. In October, the vast majority of the houses feature distinctive Halloween decorations; soon afterwards, they are decorated for Thanksgiving in

November and then immediately for Christmas, which celebration goes until 
January 6, when the carnival season starts. The houses are then decorated for the Mardi Gras in the official colors of the party: purple, yellow and green, which have become the city's official colors. When there is no specific celebration, the residents hoist flags at the doors of the houses with words like joy or even colorful banners with festive designs. It is very common to have trees festooned with ribbon bows in large gardens throughout the year. New Orleans, in short, is a permanently costumed city; there is a new mask almost every month. The city is continuously renewed, "carnivalizing" the local daily life and providing visitors with varied and renewed surprises. ([12], p. 294)

This demarcation of celebrations, in harmony with the ancestral spirit and values, permeates the geographical reading of multiple New Orleanses renewed in the crafting of emerging Africanities. The colorful pattern of the Mardi Gras-purple (justice), yellow (money/power), green (hope), created to represent the Carnival Rex in 1872, during the visit of the Russian Grand Duke, Alexei Romanoff ([6], p. 295) - is multiplied by the museums of Black craftsmanship, such as the House of Dance \& Feathers (http://houseofdanceandfeathers.org/) and the Backstreet Museum (http://www.backstreetmuseum.org/). Names renowned in the universe of local resistance for their artistic works and organizational capacity, such as Ronald W. Lewis, Victor Harris, and Sylvester Francis, contribute radically to the expansion of this rejuvenation of a Pan-African New Orleans not captured by the comparative studies of Roberto DaMatta ([13], pp. 159-183), linking the Carnival celebrations of the city exclusively to the aristocratic figure of the King. There the complex reigns in its peripheral unfolding (of times and spaces), producing other pulsating realms in sacred-profane performances.

We are dealing, therefore, with a Carnival process that emerges from this and other revelries of New Orleans as a kind of "improvised trampoline." This is affirmed in its complex web of ethnocultural significations This policy of affirmation, regardless of sticks and carrots of the public authority or the interests of the dominant society, radicalizes a multiplicity of events in various meeting places, as if other days of the week, other months, throughout the year, could translate the Afro-Amerindian power of reinvention of Mardi Gras.

A. L. Davis Park, on Lasalle Street, in Central City (a central New Orleans neighborhood), on March 25, 2018 (formerly scheduled for March 3, but extended for adverse weather reasons), was one of those out-of-season Carnival centers, as since 1970 it has been a Super Sunday venue for the gathering and performances of the "tribes" of Mardi Gras Indians. What defines the strength of the civil and multicultural religiosity of these groups is the inclusive greeting, the remembrance and celebration of the vitality and the beauty of the Afro-Amerindian spirits at important dates in Christian symbology. Carnival, as a transition to Lent, is one such date, but it is its overflow, for all the moments of effective reunion of the Afro-Amerindian communities, that supports the symbolic reincorporation of the spiritual powers (Figure 3) that the aristocracy, whether colonial or postmodern, insists on denying. 


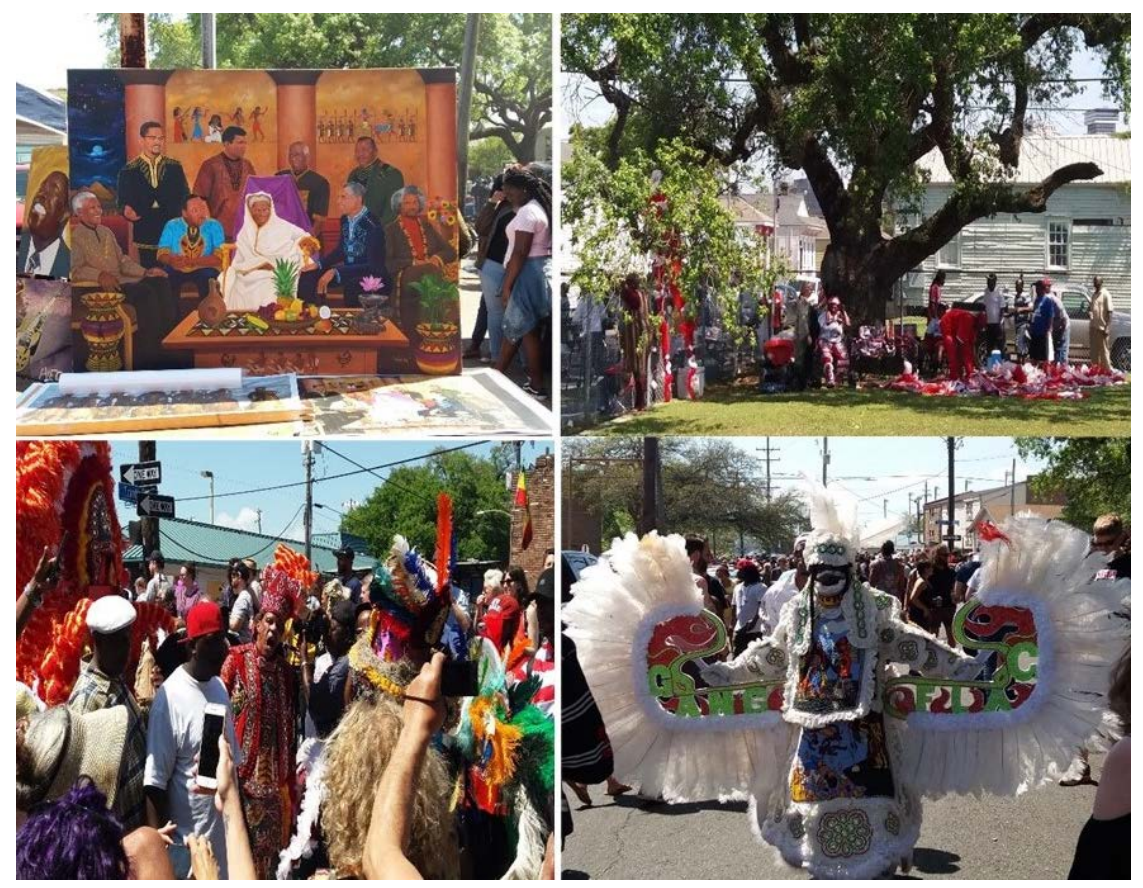

Figure 3. Photomontage of presentations and exhibitions on Super Sunday 2018. Source: The author (2018).

The Super Sunday festival, like other successful projects in the urban manifestation of an "inventive resistance" of Africanity, rebuilds the ideology of Christian fraternity, not by performing its parade in one of the neighborhoods most thickly distributed with Protestant churches and charity associations, nor by celebrating the overcoming of environmental terrors in the flood after Hurricane Katrina [14], but by marking in a ritual and festive way the political-economic empowerment that has never been won in this of many "Africans" of the extreme west, despite all the energy captured from the native ancestral spirits of America.

\section{Mythical Interpretations: Allegory of the Time on the Carnival Float}

New Orleans connects with the ritual dynamics of Carnival time via the annual dates of the Catholic Calendar, in the Gregorian model, against all resistance to reformatting and setting dates according to the proposals of astronomical societies [15] - the creation of a ritual time which extends from Advent (as preparation for the Christmas festivities) until Easter. Therefore, it is a festivity that did not lose-even with all the advancement of lay and secular values-a religious justification, because its dates continue "celebrating" the farewell to worldly/carnal goods in their last manifestations. In contrast, as the Catholic concession and pact of 4 days of "liberal" revelry has been broken, the festivities in other cities take many weeks pre-Carnival, just as it became a habit to advance them beyond Ash Wednesday, bringing them closer to the sacred dates of Lent and Easter.

But if so, how does this connection with other Carnival cities on the continent create a consolidation of Carnival within postmodern theatrical rhythms? By the 
inclusion of other religious matrices, now capable of claiming and exercising the cohabitation of revelry as an explanation of their own agenda of multiple interests. After all, a complex of festivities, events, celebrations and rites tends to include political interests, economic advantages, and social perspectives that are much broader than the perpetuation or resistance of an ethnic and aesthetic gathering. People (Asian, African, Latin, or otherwise subaltern) can pass their message through the deepest and most authentic cultural expressions, even though the infinite "modernizations" are always removing such authenticity from an "origin" traditionally claimed as the greater essence of a certain manifestation. What is on the agenda of this mythical temporality is the parameter of ordinary "inversion" translated as carnival game: the way by which the Catholic European Christian festivity became Afro-Amerindian, to the point of gaining new sacred forms to be recognized as thoroughly profane.

It is then fundamental to approach the representation of "translatinity" as a critical-creative response formulated by this sacred-profane amplitude of the Carnival process. By putting forward Latin American forms of empowerment-typical of the monolithic characterization of the South American universe and the translatin burlesque exercise (effervescent in the revelry and refused at first hand) - we find again the theoretical plot of the medieval origins of the European Carnival, as Mikhail Bakhtin did in a broad movement (upgraded, postmodern) of decolonization. The Carnival landscapes of New Orleans diffuse this tense and explosive Latin frontier into a constant landscape movement of Mardi Gras celebrations in multiple events created by the streetcar of desire. The time of festivities, of shorter or longer special cycles, creates an expression of rupture with the established order. However, if such a time is a constant in a theater space of festivities, and if ethnic-cultural contestation is found in the subaltern design of the societies most victimized by this constant-the Latin (post)colonial world-where and how were the Afro-Amerindian cultures restored, as the protagonists of the immaterial goods of the continent?

Studies on the Latin American massacre of the last five centuries leave no room for the positive recognition of the Greco-Roman heritage. Hence the need to think of Latinity in its transcendence and to channel the immanent re-elaborations that Black, Indigenous, and Mestizo societies create in the time-space sacralized by the opportunities of the Carnival celebration, although it is not easy to understand how the performance of Mardi Gras Indians has found an associative response to the cultural segregation of these groups. According to Peter Wade [16], repeated discrimination in the separation of treatment between Blacks and Indians on the continent created an almost insurmountable cultural exchange barrier.

In general therefore, the image that is formed is of separate indigenous and black identities, rather than the transcendence of that difference. This may be due, in part, to a lack of historical data. It is clear that in some places, such as the Caribbean coast of Colombia and the northeast of Brazil, the 
widespread colonial miscegenation between blacks and Indians, which resulted in the predominance of a rural, heterogeneous and mestizo population before independence, was not undone during the $19^{\text {th }}$ century and for most of the $20^{\text {th }}$ century. ([16] p. 135)

In another passage that refers to this ethnic plot, as a permanent remaking of the confrontation of the Euro-descended hierarchies, Wade uses the metaphor of mapping (representation) to remind us how much the Latinity of the cultural geography of New Orleans demands what we have called translatinity:

But the triad works in a topological way: the underlying relations of power and hierarchy between nodes retain their structure through multiple and successive distortions of the terrain upon which they are mapped. Like a subway map, it does not matter that the surface on which the structure is inscribed has the shape of a circle or a square-it can still be read as a guide. Unlike a subway map, the network connecting the three nodes is, in principle, unlimited and not fixed in the potentiality of its connections: black, white, and indigenous can acquire new connections with other nodes people, institutions and knowledge-that can change their meanings and their relations within a network that is, in any case, persistently conformed by the racial hierarchy. Thus, on the one hand, Afro-Indian mixtures show a tendency to be structured by a persistent conceptual divergence between black and Indian, which can be interpreted as a continuous result of the dominance of the white people. On the other hand, the meaning and effects of this divergence vary in time and space ([16], p. 151)

The confirmation that the conceptual divergence of Blacks and Indians reflects the permanence of a dominance of white people and Eurocentric elitism helps us to understand the ritual response of Afro-descended communities in New Orleans. It is a transcultural exercise, in the gathering of crossed identities and of the mythical greeting of the Black communities received by the indigenous spirits to reconnect with the great African Spirit, perhaps the more essential and ancestral form of what we mean in Western culture by "God." A reunion of human forces, natural and divine, absorbed by the cults of Candomblé, Umbanda, Creole drum, and Maracatu in Brazil, like so many forms of Afro-Amerindian ritual in the great western continent, colonized as "America" and marked by an explosive Anglo-Latinity. As a living master of the cultural landscape of resistance against the segregation of these "inferior" civilizations, Victor Harris (Big Chief), would say: Fire in the Hole! Fi-Yi-Yl This is also the title of a book edited by Breunlin [17] for the UNO Press's Neighborhood Story Project; an interview with Master Harris can be accessed at https://www.youtube.com/watch?v=K32hFhc8Hhg.

$F i-Y i-Y i$ is a rhythmic mantra that moves the body-spirit of the Mardi Gras Indian, connecting to a pulsating deep religiosity and yielding a magical scenic entertainment. This is what we call the interpretation of the Carnival float, the 
syncope of form and content that derails the ritual streetcar from the fixed tracks-from the pathways of colonial and modern hierarchies-to compose the new streetcar of desire, carnivalesque and postmodern, redolent of another possible society-allegorical, theatrical and restorative of a more egalitarian patrimonial landscape, able to overflow, by tribal force, the Mardi Gras Indians many times in the year and in many squares of the city.

\section{Conclusions}

The theatricality of the space with which we work in this landscape view of New Orleans comes from our analytical vector conception adopted from the methodology of Patrice Pavis [18]. The French scholar connects a geometric language of contextual forces that act on the live stage to answer the question: what are the most relevant dynamics in the constitution of the languages that make the scene? When we ask the same question in the follow-up of Carnivals in the city, outside of space, time and standard mediatization, we find a schematic structure, mapping which guides an alternative model of Latinity. According to the philosopher Gaston Bachelard, reviewed in the biographical rescue of Bontems [19], this alternative would be called a "(trans) latinity of no, a latinity of reaffirming the universe of costs and bonuses of the colonial culture open to the patrimonial reinventions of two continents-Black Africa and indigenous America-united by the hybridism of permanent creativity. The Mardi Gras Indians in New Orleans absorb the permanent role of the corpus in the scene, performatively willing to play the game of vector forces of the carnival dynamic on the scale of the city and of the entire (Caribbean) region.

The picture scheme of Figure 4 denotes this vector questioning in the bottom arrow, signs of the convergence of tensed forces: mythic-religious, political-touristic, media-ecosystemic [20]. Without them, the columns of the colonial and modern conquests-French, Creole, formed of segregations and European Latinities-would have already crushed the productions of subaltern cultures.

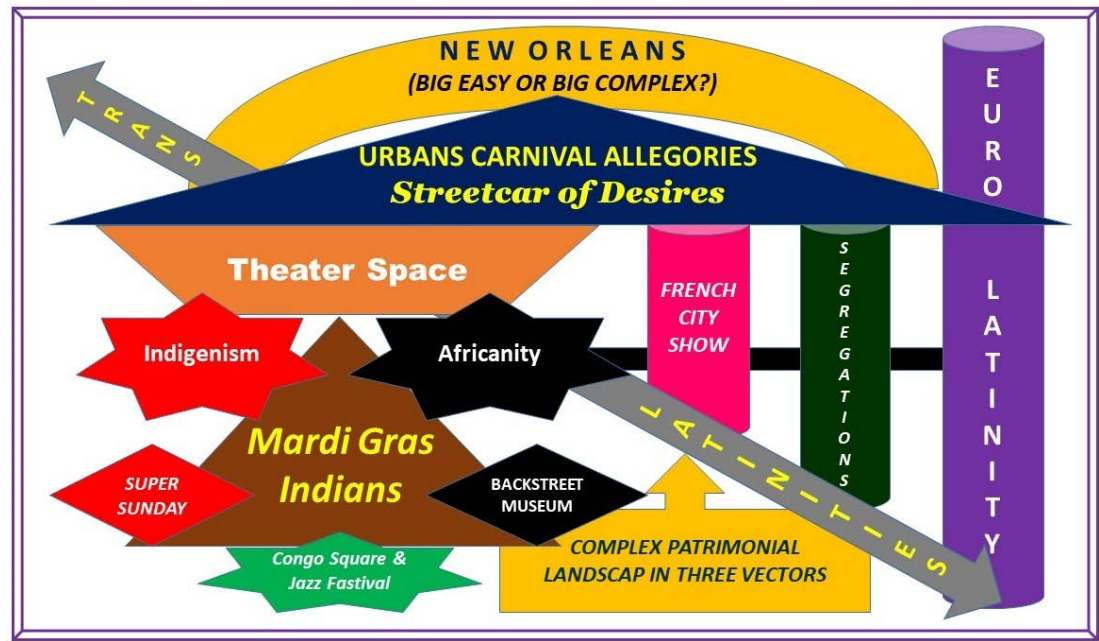

Figure 4. Map of concepts of the Carnival patrimonial landscape. Source: Author (2018). 
It turns out that as the multiform spaces of Indigenous, Mestizos and Afro-descendants gather in squares, ghettos, and events around the Carnival (as in the spectacles of A. L. Davis Park), a dynamic of resistance in the reinvented traditions, the same ones that translate the festive and ritual place into an effective patrimonial landscape with authenticity, is paradoxically close and far from the ironized kitsch of tourist brands and typifications. New Orleans's nickname, the Big Easy, demands the questioning in the structure of Figure 4. It is an urban irony that this great generative space of artistic and musical movements, especially jazz, which have served as a mystical force of overcoming, also serves as a tourist hub, with more than 10 million visitors in 2016 and the restoration of the service chain. The tragedy of Hurricane Katrina, in 2005, initiated the most recent phase of this socio-demographic and cultural crush, expelling approximately 100 thousand inhabitants from the city [21].

A decade and more later, however, the answer has been the uplifting of the same pillars of inequality, tensions, segregation and reinforcement of the French-European identity, pushing the old economy of exotic modernity [22]. Would it be possible, in the satirical and tragicomic structure of the theater space, to consider another "different" vector alignment-one less unequal-that the allegory of the "streetcar of desire" provides to this kind of city?

We do not have a solution as consistent as we would like, but the geographic approach that this cultural capital of "Louisiana" allows us provides clues to crossreference with other Carnival towns, with their dense and festive patrimonial landscapes, in other Latin American locales. Hence, New Orleans, in its theater of streetcars and voodoo, Krewes and "Indians"- -sediments the three indispensable paths to the analysis of the theater space of creative translatinity:

1) A media-scientific vector in the extravagant technologies of the performative Carnival floats, as "exotic streetcars" of the parades.

2) A political-touristic vector in the fanciful satire of kings of revelry and endless personifications of anecdotal chaos, as "voodoo of ephemeral power".

3) A mythic-religious vector in the game of the eternal return of sacred-profane times and spaces, in which the past, represented by the old and the ancestors, and the future, represented by children, communicate the same messages in the poetry of rhythm and blues.

\section{Acknowledgements}

We acknowledge the direct support of the CAPES, CNPQ and FUNCAP development agencies and the Federal University of Ceará, which provided financial conditions and infrastructure for this phase of the research. We are also grateful for the receptiveness of the US universities LSU (Baton Rouge) and TULANE (New Orleans) which, through Prof. Dr. Kent Mathewson (LSU), allowed us the opportunity to develop bibliographic and field work.

\section{Conflicts of Interest}

The author declares no conflicts of interest regarding the publication of this paper. 


\section{References}

[1] Oliveira, C.D.M. (2007) Geografia do Turismo na cultura Carnavalesca: O Sambódromo do Anhembi. Editora Paulistana, São Paulo.

[2] Williams, T. (1947) A Streetcar Named Desire. New Directions, New York.

[3] Lozica, I. (2007) Carnival: A Short History of Carnival Customs and Their Social Function. Narodna umjetnost (Zagreb), 44, 71-92. https://hrcak.srce.hr/23253

[4] Brito, S. (2015) O Carnaval e o Mundo Burgues. Revista da Faculdade de Letras, 6, 313-318. http://ler.letras.up.pt/uploads/ficheiros/3390.pdf

[5] Ferreira, L.F. (2005) Inventando carnavais: o surgimento do carnaval carioca no século XIX e outras questões carnavalescas. Editora UFRJ, Rio de Janeiro.

[6] Andrews, G.R. (2007) América Afro-Latina, 1800-2000 (São Carlos), EdUFSCar. https://edisciplinas.usp.br/mod/resource/view.php?id=2378756

[7] Gonzalez Pérez, M. (Org.) (2014) Carnavales y nación: estudios sobre Brasil, Colombia, Costa Rica, Cuba e Venezuela. 1 ed. (Bogotá) Ediciones Ántropos 1, 206-215.

[8] Nwaru, C. (2015) Upholding the Igbo Cultural Heritage through the Theatre. Art and Design Review, 3, 18-24. https://doi.org/10.4236/adr.2015.32004

[9] Wright, J.K. (1947) Terrae Incognitae: The Place of the Imagination in Geography. Annals of the Association of American Geographers, 37, 1-15. https://doi.org/10.1080/00045604709351940

[10] Alves, M.G.C. (2016) Um Bonde Chamado Desejo: A “Coisa Freudiana” Como Trajetória De Leitura. https://revistas.pucsp.br/index.php/leituraflutuante/article/download/30190/21475

[11] Souther, J.M. (2014) New Orleans on Parade: Tourism and Transformation of the Crescent City. LSU Press, New Orleans.

[12] Góes, F. (2005) Mardi Gras: Carnaval Americano na Visão de um Brasileiro. Alea, 7, 291-304. https://doi.org/10.1590/S1517-106X2005000200009

[13] DaMatta, R. (1997) Carnavavais, Malandros e Heróis: Para uma Sociologia do Dilema Brasileiro. Zahar Editores, Rio de Janeiro.

[14] Cavalcanti, M. (2009) Sobre alguns usos emergentes da história oral nos Estados Unidos: o caso do furacão Katrina. Estudos Históricos (Rio de Janeiro), 22, 196-217. https://doi.org/10.1590/S0103-21862009000100011

[15] Segura Gonzalez, W. (2012) La Reforma del Calendário: Las Tentativas para Transformar el Calendário Gregoriano. EWT Ediciones, Cádiz.

[16] Wade, P. (2018) Interações, Relações e Comparações Afro-Indígenas. In: Fuente, A., et al., Eds., Estudos Afro-Latino-Americanos: Uma Introdução, CLACSO, Buenos Aires.

[17] Breunlin, R. (2018) Fire in the Hole: The Spirit Work of Fi Yi Yi \& Mandingo Warriors. University of New Orleans Press, New Orleans.

[18] Pavis, P. (2008) Análise dos Espetáculos: Teatro, Mímica, Dança, Dança-Teatro, Cinema. Perspectiva, São Paulo.

[19] Bontems, V. (2017) Bachelard. Estação Liberdade, São Paulo.

[20] De Oliveira, C.D.M. (2017) Festas Religiosas, Santuários Naturais e Vetores de Lugares Simbólicos. Revista da ANPEGE, 7, 93-106.

http://ojs.ufgd.edu.br/index.php/anpege/article/view/6530

https://doi.org/10.5418/RA2011.0708.0007 
[21] Haney, T. and Elliott, J. (2013) The Sociological Determination: A Reflexive Look at Conducting Local Disaster Research after Hurricane Katrina. Sociology Mind, 3, 7-15. https://doi.org/10.4236/sm.2013.31002

[22] Mourão, R. (2014) O Carnaval é um Palco, A Ilha uma Festa: Da Performance Cultural à Exposição da sua Metaperformance Videográfica. MIDAS, 3. 